\title{
THE INTEGRATED MODEL OF TERRITORIAL MANAGEMENT: A BET FOR PUBLIC MANAGEMENT
}

\section{EL MODELO INTEGRAL DE GESTIÓN TERRITORIAL: UNA APUESTA PARA LA GESTIÓN PÚBLICA}

\author{
Janeth Patricia Muñoz Eraso ${ }^{1}$
}

\begin{abstract}
The current context poses new challenges in public action, which leads to a grounded understanding of the territory, the stakeholders and territorial dynamics, and the adoption of contemporary models and tools that facilitate citizen participation; the articulation of stakeholders; collaborative work; transparency; ethics and public innovation. Based on literature review, this article presents the main postulates of the public management models that serve as reference for the proposal of an Integrated Model of Territorial Management (IMTM), which helps to visualize the territorial particularities and specificities in order to propose strategies and tools that promote a comprehensive development of the territories. It is concluded that public management models present interesting principles for territorial management, however, they are not a "straitjacket" because each territorial scenario presents its own characteristics, which should be taken into account when designing public policies and territorial management plans.
\end{abstract}

Keywords: public management, public policies, public management models, territorial public management, governance, participation, actors, territory.

\section{Resumen}

El contexto actual plantea nuevos retos en la acción pública, lo cual conduce a la comprensión aterrizada del territorio, los actores y las dinámicas locales, y a la adopción de modelos y herramientas contemporáneos que faciliten la participación ciudadana, la articulación de los actores, el trabajo colaborativo, la transparencia, la ética y la innovación pública. A partir de la revisión bibliográfica, este artículo presenta los principales postulados de los modelos de gestión pública, que sirven como referencia para la propuesta de un Modelo Integral de Gestión Territorial (MIGT), que coadyuve a visibilizar las particularidades y especificidades territoriales y a proponer estrategias e instrumentos que promuevan el desarrollo integral de los territorios. Se concluye que los modelos de gestión pública presentan principios interesantes para la gestión del territorio, empero, no son "camisa de fuerza" porque cada escenario territorial presenta sus propias

\footnotetext{
${ }^{1} \mathrm{PhD}$ in Social Sciences with a Specialization in Political Studies from the Latin American Faculty of Social Sciences FLACSO, Ecuador. Associate Professor of the School of Politics and International Relations of the Sergio Arboleda University of Bogotá. Professor at the Faculty of Political Science and International Relations of the Pontificia Universidad Javeriana de Bogotá, Colombia. Email: janeth.munoz@usa.edu.co
} 
características, que vale tener en cuenta a la hora de diseñar políticas públicas y planes de gestión territorial.

Palabras clave: gestión pública, políticas públicas, modelos de gestión pública, gestión pública territorial, gobernanza, participación, actores, territorio

\section{Introduction}

The world is constantly evolving and with it, the ways in which the State and society relate to each other, which poses important challenges in terms of public management. This invites us to think about contemporary strategies that make territories, stakeholders and local dynamics visible. Which model is the most appropriate to reach territorial scenarios? Is a question that is hoped to be resolved in this article. To do so, we will take as a starting point the definition of public management, breaking down its two concepts, and public management as a discipline and its interrelation with public policies as two sides of the same coin in the decision of what is public. Next, we will examine the different models and tools of public management that have been developed, starting from the Bureaucratic Model to the New Public Service, which show their own characteristics and renewed perspectives for the formulation and management of public policies.

Subsequently, the territory will be addressed as an important category of analysis that is being incorporated into the management of public affairs through strategies and tools that facilitate the territorialization of public policies and management with an Integral Model of Territorial Management that allows public management to be grounded in local scenarios.

This text is a practical approach that serves as an aid material for those interested in public affairs under a territorial approach; observes the particular dynamics, stakeholders and interactions, and the participation, as an important tool for the management of public policies. It provides concepts, models, tools and examples that allow the understanding of public management in general and territorial public management in particular.

\section{Public management: clarification of the concept}

Public management contains two terms that have been the subject of research. On one hand, the concept of "management" is based on its etymological root "gesture" derived from the Latin gestus, a term used to refer to the body language of people, their movements, attitudes, and body postures that indicate their state of mind. Therefore, the use of the word "management" "highlights precise, timely and practical actions in order to achieve in the shortest possible time, and with the quality of the case, the purposes outlined in both the public and private spheres" (MUÑOZ, 2020, p.96). It is a broad category, whose basic characteristic evidences specific actions (MEDINA, 2008).

Management as a practice and as a discipline occurs in all spheres of public and private, individual and collective life. Its approach considers a range of multilevel management areas, such as: institutional, local, community, territorial. Therefore, the concept of management is increasingly gaining relevance as a category of analysis and its use "has become hegemonic and is associated with administrative or business, institutional or organizational conceptions and is closely linked to the notion of strategy" (MANRIQUE, 2016, p.137), as well as to planning processes, coordination and articulation of both public and private affairs.

The public, on the other hand, comes from the Latin publicus and indicates whom or what which is notorious, obvious, patent, known or seen by all. Its approach at a Governmental level acquires its own sense that is aimed at making visible a common sphere in the exercise of the relations of the State and citizenship, in which public issues, the construction of public policies and the articulation of actions, concern us all. According to SERNA (2010) implies a structure of rules that limit the exercise of State power. Moreover, those who act in the public sphere are considered publicly accountable for their actions (in particular, to citizens).

Gestion publica was incorporated into Spanish from the translation of the American term public management and the French term gestion publique. As a field of study, according to BOZEMAN (1998), public management is situated in two very different institutions: the commercial school and the school of public policy under the B and $\mathrm{P}$ approaches, respectively. In the first approach, management is much closer to traditional public administration. It is based on the 
concepts of business disciplines with specific quantitative methodologies, without making a rigorous distinction between the public and private spheres. In this perspective, the empiric importance is highlighted and is oriented towards processes, organizational design, personnel management, budget management, etc. In the $\mathrm{P}$ approach, public management was conceived as the directive management of policies. It starts from the rejection of traditional public administration, concentrating on exploring the role of the administrator or political executive in high-level policies of public organizations. This approach emphasizes the political aspects of management and its methodology concentrates on case studies, which provides a prescriptive basis based more on practice than on theory.

Although the two approaches have different origins, they agree on the questioning of traditional management, and the relevance of case studies and their contributions to theories and their implementation.

\section{Public Policy vs. Public Management: from writing to practice}

Public policies as tools for solving socially relevant or unsatisfactory problems become the road map for the generation of activities, resources, goals and results of public action. However, in practice, their implementation may reveal a gap between the formulation of policies and the reality of their application (implementation gap), which prevents the achievement of the purposes outlined in them. According to ROTH (2015, p.186-187) it is a "distance (sometimes abysmal) that separates theory from practice (...) this is why perfect implementation is perfectly unattainable".

It is at this point that public management comes into play. Following BOZEMAN (1998) this approach focuses on strategy (not business process), on inter-organizational relations (not intraorganizational relations) and on the intersection of policy and governance. In other words,

Public policy and management are two sides of the same coin: public decision. The first side corresponds to the public policy materialized in a plan, program, project, etc. what in writing is, the "should be" to address a public problem. The second side concerns "management", that is, the operationalization and implementation of public decisions. Two interdependent faces that must be thought integrally for the achievement of the purposes outlined in the governmental exercise (MUÑOZ, 2020, p. 98).

In the public management approach, the gap in the implementation of public policies led SABATIER and MAZMANIAN (1979), cited in ROTH, (2015), to propose a "Guide to good public management" that contains the conditions and premises to facilitate legislators and policy makers, an effective and efficient, and provide the possibilities for a more successful implementation. This guide contains five (5) conditions that integrate strategies, aspects of the material content of the policy (objectives and design) as well as the context and resources available for its implementation (Table 1).

Table 1: Guide to "good" public management

\begin{tabular}{|l|l|}
\hline Condition & Premise \\
\hline A sound theory & $\begin{array}{l}\text { It is necessary to have a theory of social change that firmly } \\
\text { establishes causality between the tool used and the desired } \\
\text { effects. }\end{array}$ \\
\hline A well-conceived law & $\begin{array}{l}\text { It should contain clear, unambiguous guidelines for action, } \\
\text { and should structure the implementation process in a way that } \\
\text { maximizes the likelihood that recipients will behave as } \\
\text { intended. }\end{array}$ \\
\hline $\begin{array}{l}\text { Trained and committed } \\
\text { managers }\end{array}$ & $\begin{array}{l}\text { They must have strong political and managerial skills and be } \\
\text { committed to the objectives of the law. }\end{array}$ \\
\hline Political and social support & $\begin{array}{l}\text { The program must have active support throughout the } \\
\text { implementation process from organized groups and important } \\
\text { political actors for the realization of the policy objectives. }\end{array}$ \\
\hline Favourable environment & $\begin{array}{l}\text { Importance of maintaining the socio-economic conditions that } \\
\text { gave rise to the public policy }\end{array}$ \\
\hline
\end{tabular}

Source: MUÑOZ (2020) citing ROTH (2015)

Although the proposal of SABATIER and MAZMANIAN is directed to an optimal implementation, which is rarely fulfilled in reality, it also guides the way to improve the results in a suboptimal situation, when reality does not correspond to a satisfactory state of optimization, which 
leads to increase the probabilities of a successful implementation, promoting at the same time, the creation of public value in the results of public policies and public management, and that "takes place in the public sphere. In the dialogue between ordinary people and public administrators according to many topics and problems that can be solved, through the convergent participation of these actors in the public space" (SANTILLÁN, 2017, p.185).

For Mark Moore, important exponent of public value, the main result of public management should be the production of public value. It is defined as the value generated by the State through the quality of the goods and services it offers to users and/or the target population of the policies (MOORE, 1998). In this perspective, public management is nourished with content by making individuals visible as citizens and not as mere clients. According to the author, citizen satisfaction is the best way to measure public value.

From the identification of public management as a focus of analysis and its articulation with public policies, models of public management emerge. These are located in different historical moments, aimed at organizing public administration, improving administrative processes, promoting coordination mechanisms and articulation of different stakeholders and strengthening the management of public employees and official workers, in the management of resources, the operationalization of public policies and in contemporary practices of transparency, collaboration and citizen participation.

\section{Public Management Models: in practice}

Public management as a discipline presents a historical evolution that shows a series of models, tools and strategies that aim to optimize the action of the State and to make visible different stakeholders that interact in the public arena. Its natural evolution indicates different forms of management, which have entailed processes of continuous adjustment and adaptation to the changing dynamics that are emerging and that currently take into account aspects such as globalization, citizen participation, actors, territory, and local dynamics.

In this framework, a series of models are evident, that in different historical contexts, propose orientations in the public sphere, ranging from hierarchical bureaucratic perspectives to more horizontal, transparent and collaborative strategies to be implemented.

\section{From Bureaucracy to the Bureaucratic Model: the hierarchization of public action}

In the nineteenth century the classical model of public administration is based on bureaucracy, a term proposed by Max Weber that suggests an ideal form of organization, efficient and effective, in order to accomplish the principle of legality in administrative processes. The Bureaucratic Model is constituted worldwide, in a dominant paradigm of public exercise, by laying the foundations of the Welfare State through the application of a series of rules, procedures and "values aimed at maintaining the proper functioning of the institutional organization" (MUÑOZ, 2019, p.75) under a legal-rational logic aimed at obtaining maximum efficiency in achieving organizational objectives.

The Bureaucratic Model establishes the parameters of public action, under a centralized and hierarchical view, where the State is the axis of collective decisions in a formal, gridded scheme of rules and norms, standardization of processes, division of labor, specialization of functions, impersonal treatment and an institutional system of meritocracy that aims to position the best workers in the State.

For Weber, the Bureaucratic Model is the system of organization of public power that can overcome the charismatic and traditional systems that tend to degenerate into clientelism and patrimonial logics in public administration (RAMIÓ, 2020, n.p).

In the 1980s, this model entered into crisis because the State could not provide a timely response to all social demands, nor could it continue to be all-powerful in the resolution of public affairs, which left in evidence a slow entity, absent from social dynamics and wasteful of public resources. AGUILAR (2015) indicates that the model reflects a wasteful regulatory burden that for the procedures was highly inefficient, ineffective and very ineffective both in the provision of services and in state action.

The poor results of the Bureaucratic Model in the management of public affairs has blurred the foundational purposes of bureaucracy, leading to the fact that, in popular jargon, this concept is 
considered in a derogatory manner and associated with slowness in technical and administrative processes, corruptive practices, excessive bureaucratic paperwork, incompetent officials, automotive work and the "dehumanization" of the State. However, with its contributions and limitations, this model shows a significant advance in the attempts to organize and rationalize the activity of the State and its institutions. It leaves an important mark on the normal way of organizing contemporary societies and becomes a fundamental component of all modernizing processes so far known (MUÑOZ, 2020).

Currently, it is not obvious to approach a concrete case that integrates all the characteristics of the Bureaucratic Model, due to the dynamics and transformations that have taken place in public management, which increasingly invites to adjust and rethink its models, strategies and tools. However, traditionally, institutions such as the church, the military forces and the justice system have been associated with the Weberian model as they reflect several of its traits. They are hierarchical organizations of command and control, which play a significant role in the configuration of that considered to be public.

\section{The New Public Management Model: the citizen - client}

Faced with the crisis of the bureaucratic model and the changes in society, different theories and approaches began to be put forward on how to manage the public sector effectively, efficiently and economically, which implied a challenge for governments to change their traditional patterns of administration and fostered a favorable climate for establishing managerial reforms, both in developed and developing countries entangled in a "New Public Management" (NPM) which "it is about replacing a bureaucratic management guided by the impersonal rule, by a management by contract, guided by the market" (ROTH, 2015, p. 206).

The neoliberal policies of the 80s, strengthened the NGP with the incorporation of managerial and business principles of the private sector within the public sector; focused on highlighting the role of the State under the premises of efficiency, effectiveness and economy and its proximity to the needs of users, in a citizen-customer perspective. Similarly, it reconsiders the way of thinking about management in the public sphere, based on a public finance approach, which includes the incorporation of tools and strategies such as privatization of public enterprises, management for results, compliance with organizational goals, decentralization of government agencies, outsourcing, competition, strategic planning, quality management, process management, empowerment of senior managers, among others. "It was a new global trend that arrived in Latin American countries in the late 1990s and, for many years, became the hegemonic paradigm for public administration" (Valdez, 2019, p.325).

Despite the progress made with the NGP, at the end of the 20th century and the beginning of the 21st century, the model began to be considered "anachronistic" and with "inapplicable" alternative solutions (RAMÍREZ-ALUJAS, Á., 2010). "What was initially an observable phenomenon, the failures of the State due to bureaucratization, became a reason for dismemberment of the administrative apparatus, rather than a reason to improve it" (FONTAINE, 2015, p.78).

According to AGUILAR (2015), the new crisis presented in the NGP can be explained by the great emphasis that the NGP made on the principle of efficiency in public management, causing other components such as citizen participation and the articulation of new decentralized entities to be left aside. In agreement, MEDINA (2008) affirms that the initiatives of flexibility in the relationship between actors generated arbitrariness in decision making. Likewise, citizen participation was limited to micro issues and the private sector was not sufficiently effective both in the solution of social problems and in the management of public services.

In the Latin American scenario at the end of the 1990s, the Latin American Center for Development Administration (CLAD) began to discuss NPM as "a new public management for Latin America" framed in strengthening of citizen participation and social inclusion in the administrative process. In 2010 a "Latin American public management for the 21st century" was proposed with an agenda in 5 axes: democratization of public management, new management technologies (egovernment tools), management for development-oriented results, and governance mechanisms (ROTH, 2015).

Experiences of the NGP. The introduction of neo-governmental reforms indicated a break with the classic paradigm of Weberian administration, promoting public policies oriented towards the sale, privatization and dismantling of the vast majority of public enterprises, as well as 
deregulation and administrative simplification promoted through legal reforms, the participation of the national and foreign private sector in services and enterprises formerly of a public nature through concessions or co-participations (Valdez, 2019). The predominant form of privatization has been the transfer of responsibility for services and infrastructure investment to private institutions on the basis of long-term concessions. Most Latin American countries have privatized their telecommunications, electricity, gas and, to a lesser extent, water and sanitation services. Brazil, for example, between October 1991 and June 1996 privatized fifty large state-owned enterprises, such as Usinas Siderurgicas de Minas Gerais (USIMINAS) or the National Steel Company (CSN).

In Colombia, telecommunications companies were privatized, granting the concession to private operators. GIRALDO (2016) indicates that in that decade, the telecommunications industry in the country, had a particular development compared to other Latin American countries, which led to a progressive process of denationalization, which followed the pace and interests of each of the governments in power, which finally materialized after 2000. Most of the experiences of privatization of telecommunications show that the weakness of an institutional and regulatory framework has prevented the development of the industry in the hands of private enterprise, which has benefited from the substantial revenues earned in this strategic sector, without producing improvements in its quality or coverage.

In Mexico, the privatization of the railway system granted concessions for 20 to 50 years to private groups. Likewise, the Fox government sold the Mexican satellites (SATMEX) to the private sector, since the costs of their maintenance were too excessive and did not generate any collective benefit.

\section{Multilevel Governance: from vertical to horizontal relationships}

The new social and political realities pose important challenges in public management not only in terms of administration but also in the way of relating to and operationalizing public affairs in the face of the inadequacy of governments to address social problems in different territorial contexts. Thus, the ways of doing the bureaucratic model are moving towards a governance model in which "there is a growing need for activation and construction of social capital, transversely and a comprehensive approach to interventions (CASTILLO, 2019, p. 20).

In this perspective, the Governance Model proposes mechanisms of interaction between the State and the various public, private and mixed stakeholders in the management of the public, which establishes more horizontal, coordinated, articulated and collaborative relationships, that generated a transformation in the traditional models of governing, where according to ARCINIEGAS (2019), what was unidirectional goes towards a more bidirectional model, which expands the interactions between those who govern and the governed, increasingly blurring the boundaries that separate the State and society.

Although the postulates of governance seek to promote citizen participation through the principles of co-responsibility and subsidiarity, they have also been subject to criticism (RESTREPO, 2017; TRIGUEROS, 2015) that point out the prioritization of interests of both the private sector and powerful social groups that manage to co-opt the networks to benefit themselves. Otherwise, the lack of response of governance to some traditional challenges of public management, such as transparency, efficiency and accountability, among others.

However, the current public action poses the challenge of assuming an Integral and multilevel Governance Model, which contemplates the particular contexts and enables the integration and effective participation of the various stakeholders involved public affairs management, based on responsible collective action, on collaborative and transparent work, and on an overall vision that aimed to achieve the goals set and to promote the effective and sustainable development of communities and territories.

A case of multilevel governance. The materialization of the governance model can be seen at various levels in the project "Water management for adaptation to climate change" promoted since 2010 by the International Union for Conservation of Nature (IUCN) in order to improve the capacities of decision makers to develop national plans, strategies and policies for adaptation to climate change. At the regional level, Mexico, Guatemala, El Salvador, Honduras, Panama and Costa Rica decided to work together for a better water management strategy. This initiative included the development of local capacities for water management and the care of the ecosystems that produced it. At a national level, each country has a national hydric resources strategy. At a local level, it is a "localized" 
governance of hydric-resources, where decisions on its management and administration involve communities and local governments, in response to the particular needs of each population and in a specific geographical location (community, municipality or basin). This facilitated the interaction of stakeholders to analyze the situation, detect issues, define goals and priorities towards those hydric resources, and implement actions.

An example of this is the Buenavista Micro-watershed Committee in the Mexican Coatan, which is made up of representatives from each of the ejidos: Azteca, El Aguila and Progreso, which make up the micro-watershed. Its creation emerged from the interest of different communities to have a communal organization at the micro-watershed level to promote the conservation of natural resources and foster socioeconomic development in their communities.

\section{From an Open Government Model: to an Open State}

As a new emerging paradigm of governance, open government emerged in recent years as a contemporary model that aims to establish closer and reciprocal relations between the State and the citizens, becoming an interesting strategy to address public affairs and public policy processes from "the generation of communication channels to work with society and individuals in order to co-create public value, merging the intensive use of Information and Communication Technologies, with different forms of management, planning and administration" (NASER and RAMÍREZ-ALUJAS, Á., 2014, p.16).

This model integrates three principles: transparency, collaboration, and participation, which together become the fundamental bases for effectively bringing the State closer to its citizens, in what is now known as the "open State", an approach that promotes openness strategies beyond the governmental level linked to the traditional executive power.

Transparency is a condition for citizen participation and control and is especially associated with accountability and access to permanent, understandable, complete and timely information. However, OSZLAK (2013) points out that information is seen as one of the five resources of power that states generally have, and, in that sense, public officials tend to hide information that discredits their management, or, on the contrary, disseminate information to show achievements and significant progress. Thus, transparency "does not have its own entity; it is the stakeholders, the institutions and their way of proceeding that can be called transparent. All those acts that seek to guarantee the right of access to public information can be defined as acts of transparency" (NASER, FIDELEFF and TOGNOLI, 2020, p. 15).

Collaboration establishes a form of horizontal relations between different actors (authorities, citizens, civil society organizations, public servants, NGOs, private companies, etc.), in different sectors and at different territorial scales. This is "essential to ensure effective and efficient implementation of actions committed to open government action plans" (NASER, FIDELEFF and TOGNOLI, 2020, p. 23). This category provides an opportunity for public policy advocacy, as it ensures greater impact and sustainability through cooperation with strategic stakeholders in a common bid for territorial management.

Citizen participation, as a human right, is articulated to a democratic process of public management, which should be "practiced in all stages and processes of the public policy management cycle (design and formulation, implementation, follow-up, evaluation), in all sectors and at all levels of government (national, regional and local)" (NASER, FIDELEFF and TOGNOLI, 2020, p.15), and constitute a mechanism for non-state actors to play an active and proactive role in the decisionmaking process concerning public policies. However, according to MUÑOZ and FONTAINE (2019), as it is a key element and a fundamental condition for promoting democracy and socioeconomic development, the participation of social actors in public action is one of the greatest challenges in the transformation of the democratic rule of law.

In addition to the above, the importance of open data as a key tool for the purposes of open government is summed. Since 2009, open data platforms have been launched with the purpose of encouraging the participation and interaction of governments with multiple sectors (RUVALCABA, 2020) and at different territorial scales as a stake to reach difficult access scenarios, although in practice, the latter is still a challenge for several Latin American countries.

Since 2011, the open government approach has gained strength worldwide with the establishment of a common agenda that evidences initiatives that seek to promote open government globally, such as the Open Government Partnership (OGP), an international platform that promotes 
governments to be more open, transparent and responsive to the needs of citizens. This initiative was led by the governments of the United States and Brazil, and today it includes approximately 78 countries and a growing number of local members that work together with thousands of civil society organizations to strengthen transparency policies, simplification of procedures and citizen participation.

Currently, the diverse processes of open government developed, have crossed borders, becoming a global stake, which expands the look towards an Open State that encompasses the principles of Open Government to all levels and branches of government, which involves the promotion of public policies that transcend governments and place citizens and their contexts, at the center of public action:

Install the theme as the axis of the processes of transformation of the public sphere in the region, beyond the governments in office and beyond electoral cycles, tracing a footprint that transcends the immediacy of political change, as a State policy and as a style of public management (RAMÍREZ-ALUJAS, Á., 2020).

According to BÁRCENA (2020), an Open Government calls for a significant increase in transparency, access to information and accountability, must, in light of the COVID-19 pandemic, ensure that the financial resources established as a response and to recover are used efficiently and effectively.

Cases of Open Government. In several Latin American countries, open government strategies and tools are evident, especially since 2012. For example, in Chile, at the beginning of that year tan strategy named "Chile without paperwork" was implemented. This strategy was integrated to the initiative ChileAtiende, which contains a web portal (www.chileatiende.gob.cl) and a call center to provide information, procedures and benefits of public institutions closer to the country citizens. In Colombia, tools such as Law 1712 of 2014 on Transparency and Access to Public Information, the creation of the Royalties Map, the Open State Portal (www.agacolombia.org), among others were created to establish the foundations of the approach between the government and its citizens. In Buenos Aires, Argentina, an Open Government Ecosystem has been implemented through a series of platforms (www.buenosaires.gob.ar) and coordinated mechanisms to bring public management closer to citizens, generate instances of participation, strengthen data openness and promote innovative accountability mechanisms.

At a local level, the case of Nariño's department in Colombia, in which a monitoring system for public management was introduced to its local stakeholders, promoting citizen participation in public investment through the Open Government of Nariño -GANA- platform (www.gana.nariño.gov.co), which is an innovative strategy that has led to positive results in terms of public management. However, according to RESTREPO (2017), special emphasis has been placed on the principle of transparency as an articulating axis of the other two principles, and on the use of ICTs, causing, according to the author, a barrier on the principles of participation and transparency in the territory, while there a great digital gap of citizens due to existing access restrictions, and difficulties of rural citizens to technology.

Since 2018, Nariño has been part of the Open Government Alliance and has developed its first Action Plan 2019-2021 with three commitments called: Coffee with Data, Environmental Democracy and Nariño Decides. According to the Regional Observatory of Planning for the Development of Latin America and the Caribbean, one of the most outstanding strategies in the promotion of open government in this department is the implementation of the Municipal GANA strategy, which are mechanisms that allow citizen participation in decision-making on budget execution of their municipalities, by allowing them to participate of project's investment decisions.

\section{From the traditional civil servant to the public servant: the New Public Service}

The traditional view of public employees and official workers as those responsible for the administrative, operational and technical functions of governmental entities also shows a variation in the context of contemporary public management, which leads to the visibility of a New Public Service (NPS) aimed at serving and empowering citizens while managing institutions and implementing public policies. It is a change management approach, which needs of prepared people with a sense of institutional belonging to promote an effective achievement of public policies and encourage the development of public value.

The New Public Service poses an important transformation in the denomination of the public "civil servant", traditionally articulated to the role of the State to fulfill certain purposes, related as 
a "public function" in the framework of a legal corpus, and in tune with the Weberian legal rationality. The concept of public "servant", on the other hand, is based on the postulates of governance and open government, highlighting among other concepts such as, citizen participation, transparency, total quality, innovation, leadership, public ethics, articulation and continuous improvement in the processes of the public sector. This model is "the backbone of the construction and development of the concepts of public management, public service and citizenship, as well as the relations between citizens and public administrations" (PEREIRA and JARÁIZ, 2015, p.74.). The variation proposed by the NSP is:

Transforming the perspective of the traditional public function, towards a high standard quality public service, which encompasses in citizens as active subjects of rights, so that their expectations and interests are placed at the center of attention in a democratic framework that implies, among other things, the search for the public interest as the ultimate goal, citizen empowerment and the generation of public value (MUÑOZ, 2020,

The current dynamics pose important challenges in the New Public Service that lead to position and maintain it as a paradigm that lays the foundations of a true public management which integrates, among other things, the professionalization of public servants, incentives to the vocation of service, public innovation and timely and transparent attention to social social demands. According to MARIÑEZ (2017), it implies new delivery methods of public services, which go beyond the governmental (innovation in the public sector) to involve a civic commitment, expressed in collaborative terms between public officials, the private sector, citizens and civil organizations for the co-creation of methods, techniques and skills, making use of information and communication technologies. Along these lines, innovation should aim not only to produce changes in values, attitudes, processes and leadership, but also to provide relatively stable public services.

The strengthening of skills and competencies for the performance of public servants is today more than ever a responsible stake of governments to face the current dynamics that show social issues of global and local impact. Requiring timely attention and leadership of public servants to accurately reach territorial citizens, as PEREIRA and JARÁIZ (2015) suggest when they say that only through the creation of democratic tools that facilitate decision-making in an agile and effective way, effectively involving the citizen and taking into account their opinions when determining the path to follow. It will be viable to preserve the strength of institutions in democracies, which have been cracking and becoming a matter of great susceptibility.

Experiences of the New Public Service. In the processes of modernization of the State, there are several experiences that bring us closer to the New Public Service. In Mexico, for example, various modernization and updating strategies have been implemented through professionalization programs for public servants to acquire greater skills, knowledge and experience, criteria and commitment that have resulted in public servants prepared to take on cases and situations that correspond to their position. In Brazil, a unique website was launched for all government services (www.servicos.gov.br) and the most basic processes of public services have been automated taking into account: citizen identification and login, and the management of service processes, including requests, notifications, delivery and evaluation. In addition, a set of innovation tools and technology services have been used to act as a building blocks for governmental teams to create digital services. Finally, they have begun to change the design processes of the service provided to adapt to new digital interfaces that deliver a better end-user experience.

In a local scenario, the case of San Pedro Garza García, in Nuevo León, Mexico indicates empirical evidence of the managerial process of the New Public Service at the municipal level, within a family social policy framework, led by the Municipal Institute of Family (Infamilia) which integrated a public program that emerged in 2010 called "Papás en Red" (parents network) who linked and interacted to strengthen the comprehensive education of their children and the improvement of their environment. This strategy improved family education and developed programs that address public needs through collective efforts and processes of collaboration and leadership. Infamilia's public servants help citizens to coordinate actions based on dialogue and respect for people rooted in values of citizenship and public service.

\section{The Integrated Model of Territorial Management: a bet to territorial public action}

Public management under a territorial approach considers social, environmental, economic and political aspects that lead to propose a model that integrates the most appropriate strategies and tools of current models of public management, which allow a comprehensive and grounded vision to 
the particularities and territorial specificities. According to GALLICCHIO (2004, 2010a, 2010b) it is a question of moving from a vertical and sectorial centralist logic, to a horizontal network logic, with the territory as the ideal space. In this sense, management of the territory, according to MEDINA (2008) calls for a differentiated view based on the interaction of the government institutions, the private sector and the community in the undertaking of jointed and coordinated actions aimed to obtain visible and satisfactory results on objectives that come from the particular interest to the common action in a territory determined by specific characteristics and identified in its purposes. Therefore, challenges such as: "to move in complexity; to govern through networks and not hierarchies; to be guided by influence and not through the exercise of authority; to relate more than to command" GALLICCHIO (2004, p.60), are posed by the territorial management approach.

\section{Territorial models, strategies and tools}

The models, strategies and tools of public management can be articulated with contemporary perspectives such as an Integrated Social Management (ISM) (MEDINA, 2008) and with various Territorial Development Strategies (TDS) (ALBURQUERQUE,2007,2010; ALBURQUERQUE Y PÉREZ, 2013; GALLICHIO,2004,2010; MUÑOZ,2020) which, as a whole, take as a unit of analysis the territory, its particularities and specificities, and a range of public, private and mixed actors, as the main goals of territorial development initiatives and strategies.

The Model of Integral Social Management - MISM-.

The Model of Integral Social Management -MISM- is based on democracy as an essential foundation for territorial management and for the promotion of a participatory model for the designing of public policies contextualized to local realities. According to MEDINA (2008), it is a set of actions undertaken by the public administration and its institutional interaction that is formulated as a purpose, to make governmental and institutional action more effective, and the implementation of public policies that improves the quality of life of its population, articulating it to some level of community participation.

The MISM integrates six key variables: territories, scenarios, population, themes or situations, inter-sectorality and participation (Table 2).

Table 2: Integrated Social Management (ISM) Variables

\begin{tabular}{|l|l|}
\hline Variable & Definition \\
\hline Territories & $\begin{array}{l}\text { A space in which a complex network of relationships is developed, } \\
\text { established by different actors in accordance with the particular ways in } \\
\text { which social and institutional power operates. }\end{array}$ \\
\hline Scenarios & $\begin{array}{l}\text { Those in which the daily life of the inhabitants takes place. Each one with } \\
\text { an offer of care and service. }\end{array}$ \\
\hline Population & $\begin{array}{l}\text { Defined by its particular characteristics that make it identifiable in terms of } \\
\text { care and rights. }\end{array}$ \\
\hline $\begin{array}{l}\text { Topics } \\
\text { or situations }\end{array}$ & $\begin{array}{l}\text { Focusing aspects aimed at generating improvement processes, from two } \\
\text { different approaches: in relation to sector development and in relation to } \\
\text { specific problems. }\end{array}$ \\
\hline Inter-sectorality & $\begin{array}{l}\text { Processes, strategies and actions aimed at establishing an operational } \\
\text { dialogue between the institutions of the different sectors, in order to } \\
\text { optimize efforts and resources for the improvement of the quality of life. }\end{array}$ \\
\hline Participation & $\begin{array}{l}\text { How the social and institutional conditions are created so that the individual } \\
\text { and the community become managers of their own expectations of life and } \\
\text { well-being. }\end{array}$ \\
\hline
\end{tabular}

Source: own elaboration based on Medina (2009, p. 26-39).

Additionally, the MISM poses four requirements (Table 3) that transform the way policies are territorialized and in guarantying human rights by developing and strengthening democracy at the territorial level. 
Table 3: Requirements for Integrated Social Management (ISM)

\begin{tabular}{|l|l|}
\hline Item & Requirements \\
\hline 1 & $\begin{array}{l}\text { Moving from diagnoses to readings of micro and macro contexts that allow } \\
\text { us to detect not only the existing situation but also its structural and } \\
\text { strategic solution. }\end{array}$ \\
\hline 2 & $\begin{array}{l}\text { Moving from a focus on delivering services to approaching local } \\
\text { development in a holistic and sustainable manner. }\end{array}$ \\
\hline 3 & $\begin{array}{l}\text { To stop seeing the community as beneficiaries and to relate to it as citizens, } \\
\text { subjects of rights and as people who participate. This point is consistent } \\
\text { with the New Public Service Model. }\end{array}$ \\
\hline 4 & $\begin{array}{l}\text { Moving from fragmented planning by independent units called projects, to } \\
\text { integrated planning in specific territories with social actors that have an } \\
\text { impact on it. }\end{array}$ \\
\hline
\end{tabular}

Source: own elaboration based on Medina (2009, p. 26-39)

In this framework, the MISM is articulated to the Model of Participatory Public Management by establishing in practice, horizontal and complementary relations between the State and civil society under a human rights approach. Thus, community participation articulated to the management processes is fundamental not only in the design of public policies but also in their implementation, which implies, according to GALLICHIO (2010), that the national authority sets the course and the local level executes it. Therefore, territorial policies are convergent national and territorial policies, where the articulation is generated from local stakeholders, in a collaborative management environment, which promotes horizontal interactions between the different actors involved in the territory.

\section{The Integrated Model of Territorial Management and its tools}

The proposal for an Integrated Model of Territorial Management (IMTM) includes tools and strategies that are in line with the main models of public management (Table 4), based on the New Public Management for the Territory, under a citizen-territorial perspective and with tools such as strategic planning, process management, territorial quality management and Management for Results with territorial value (MRTV), in which the worldview of the actors and the territorial culture are the basis of the developed strategies.

The Territorial Governance Model gains strength at different territorial scales as it is proposed as a multilevel governance that is based, according to ROSAS, et. al (2012, p.124), on the interaction of interests and actors present in the territory. The formation of this structure allows the development of a "shared" territorial vision, which is essential to achieve sustainable territorial cohesion at different levels, from the local to the supranational.

Territorial governance contains tools such as networks of actors, partnerships, competitiveness agreements, and strategic alliances, which promote the participation and interaction of different actors for jointed territorial management. In the Colombian case, territorial governance becomes a relevant mechanism in the framework of the Peace Agreement signed in 2016 between the Colombian government and the Revolutionary Armed Forces of Colombia (FARC), by promoting the articulation of actions in the implementation of Development Programs with a Territorial Approach (DPTA), that require a common and coordinated commitment of the different entities involved in the affected territories by the armed conflict, illicit economies and poverty. The DPTA's are main tools of public management that are committed to a Comprehensive Rural Reform in the country.

The Territorial Open Government Model outlines an important challenge not only at a macro government level but also at the local government level with the promotion of strategies and tools that identify the territorial features and characteristics to bring the government closer to territories with little visibility, through communication channels such as satellite telephony, digital platforms and information systems that promote the participation and access of citizens, especially rural 
citizens, and with transparent information, facilitate the monitoring of public policies and their accountability.

The New Territorial Public Service proposes the preparation of professionals and public servants as "territorial managers" with a specific skill-set and competencies to work in different territorial contexts, able to apply methodologies and successful pedagogical and communicational strategies that facilitate the understanding of communities and territorial dynamics. It is also relevant to create an institutional framework that integrates territorial development committees, citizen participation councils and government leadership teams that promote public innovation, collaborative governance and territorial development with a cultural identity.

In addition, the models and strategies under a territorial approach and in the framework of an Integrated Model of Territorial Management, aim for a comprehensive look that accurately lands public management models, and, as MUÑOZ and FONTAINE (2019, p.103) rightly point out, allow:

To "set in motion" the state apparatus, through the accurate, punctual and practical operationalization of a set of actions and strategies that lead to the effective achievement of the objectives and goals outlined in public policies. Well-designed policies are useless if they do not have clear action plans that generate satisfactory results for the target population in terms of public value.

Table 4: Integral Model for Territorial Management- IMTM-.

\begin{tabular}{|l|l|l|}
\hline Model & Tools & Strategies \\
\hline $\begin{array}{l}\text { The New Public } \\
\text { Territory -NGPT-. }\end{array}$ & $\begin{array}{l}\text { - Strategic Planning } \\
\text { - Process management } \\
\text { - Territorial quality } \\
\text { management } \\
\text { - Managing for Results with } \\
\text { Territorial Value }\end{array}$ & $\begin{array}{l}\text { - Common vision of the territory. } \\
\text { - Entrepreneurial vision. } \\
\text { - Promotion of public value. }\end{array}$ \\
\hline $\begin{array}{l}\text { Territorial } \\
\text { Governance Model }\end{array}$ & $\begin{array}{l}\text { - Stakeholder networks } \\
\text { - Public-Private Partnerships } \\
\text { - Strategic Alliances } \\
\text { - Competitiveness agreements }\end{array}$ & $\begin{array}{l}\text { - Mobilization and participation of } \\
\text { actors (youth, women and vulnerable } \\
\text { population (ethnic groups). } \\
\text { - Articulation and coordination of } \\
\text { policies, programs and projects }\end{array}$ \\
\hline $\begin{array}{l}\text { Territorial Open } \\
\text { Government Model }\end{array}$ & $\begin{array}{l}\text { Digital platforms } \\
\text { Information systems } \\
\text { Databases } \\
\text { Territorial observatories }\end{array}$ & $\begin{array}{l}\text { - Access to transparent and timely } \\
\text { information. } \\
\text { - Participation mechanisms } \\
\text { - Accountability }\end{array}$ \\
\hline $\begin{array}{l}\text { New Territorial Public } \\
\text { Service }\end{array}$ & $\begin{array}{l}\text { - Territorial development } \\
\text { committees } \\
\text { - Participation Councils } \\
\text { - Leadership teams }\end{array}$ & $\begin{array}{l}\text { - Strengthening the skills and } \\
\text { competencies of public servants. } \\
\text { - Formation of a territorial institutional } \\
\text { framework. } \\
\text { - Local public innovation } \\
\text { - New powers and resources for local } \\
\text { authorities }\end{array}$ \\
\hline
\end{tabular}

Source: Prepared by the authors based on Muñoz (2020).

\section{Conclusions}

Current phenomena pose new challenges in public action related to the participatory construction of public policies and the promotion of models, tools and management strategies grounded in territorial contexts, where the stakeholders, territorial scales and local dynamics play an important role in the integral development of the territories.

The evolution of the approach to public management entails a historical perspective that should not be ignored, since it allows us to learn from the experiences and lessons acquired by different models, starting with the Bureaucratic Model, which lays the foundations for a rational and legal organization, with a normative, hierarchical and impersonal approach. With its exhaustion, the New Public Management becomes real, under an economic perspective based in an effective, efficient, economical, and citizen-customer view. The Governance Model establishes horizontal and collaborative relationships between the Government and a range of public, private and mixed actors 
for the social management of public affairs. Open Government and the New Public Service incorporate more participative, transparent, collaborative and personalized tools and strategies, based on democracy and human rights, addressing people as citizens, under the contemporary approach of an "Open State". All of these perspectives with their pros and cons contribute to a holistic view of public affairs.

However, managing the territory is not an easy task. The diverse models, tools, and strategies enable a path. However, it is not a matter of imposing homogeneous concepts or outlines while each territory has different social, economic, political and environmental characteristics, which should be taken into account in public policy processes and management plans, encompassing a view to promote sustainable development and the well-being of both urban and rural territorial communities. In this scenario, prepared personnel with specific skills and competencies are needed to accomplish the challenges of public management at different territorial scales. They become the "face" of the Government and its institutions.

The commitment to a comprehensive model that integrates the different postulates of contemporary models in public management leads to the proposal of an Integral Model of Territorial Management (IMTM) that links land tools and practical tools to processes of administration, planning, articulation and public service with a territorial approach, in order to make state action more efficient, effective and equitable. In this search, analyzing public problems in the territorial realities is an important approach, because it facilitates the drawing of a common roadmap for territorial governance, citizen participation, self-management and community co-management.

The theory and practice of public management becomes an enriching approach to address public issues that require innovative strategies to operate public policies, which transcend a quantitative and instrumental perspective, and open a spectral, comprehensive and humanized perspective, according to the dynamics of the different urban and rural contexts, which requires a dose of creativity, dynamism and sensitivity to achieve a better understanding of public affairs and to shape more equitable, transparent and effective social action in territorial scenarios.

\section{Acknowledgments english version}

Joseph David Schneider

\section{References}

ARCINIEGAS, M. Los fallos en el diseño organizacional del Departamento Fundación Padre Lorenzo Massa del Club Atlético San Lorenzo de Almagro. Tesis de Maestría. FLACSO. Sede Académica Argentina, Buenos Aires, 2019.

BÁRCENA, A. Importancia de los principios del Gobierno Abierto para el monitoreo de recursos dirigidos a la recuperación pospandemia. Cepal. Recuperado el 20 de marzo de 2020 de https://www.cepal.org/es/noticias/alicia-barcena-subraya-importancia-principios-gobierno-abiertomonitoreo-recursos-dirigidos

AGUILAR, L. F. Gobernanza y Gestión Pública. Mexico: Fondo de Cultura Económica, 2015.

ALBURQUERQUE, F. Teoría y Práctica del Enfoque del Desarrollo Local. Observatorio Latinoamericano del Desarrollo Local y la Economía Social, (0), p. 39-61, 2007.

ALBURQUERQUE, F., y PÉREZ, R. El Desarrollo Territorial: Enfoque, Contenido Y Políticas. Revista Iberoamericana de Gobierno Local-RIGL, (4), p.1-24, 2013.

BOZEMAN, B. La gestión pública. Su situación actual. (B. Bozeman, Ed.), La Gestión Pública: su situación actual. (1st ed., p. 550). México: Fondo de Cultura Económica, 1998.

CASTILLO, J. Hacia un modelo de gobernanza en red que asuma la mayor complejidad. Athenea Digital 19(1), p.1-27, 2019 
CONEJERO, E. Innovación social y nuevos modelos de gobernanza para la provisión de bienes y servicios públicos. Estado, Gobierno, Gestión Pública: Revista Chilena de Administración Pública, (27), p. 5-39, 2016.

FONTAINE, G. El análisis de políticas públicas: Conceptos, teorías y métodos. Quito-Barcelona, Flacso-Anthropos, 2015.

GALLICCHIO, E. El Desarrollo Local: ¿Como combinar gobernabilidad, desarrollo económico y capital social en el territorio? Cuadernos de CLAED, p. 55-68, 2004.

GALLICCHIO, E. El Desarrollo Local: ¿Territorializar Políticas O Genera Políticas Territoriales?. Reflexiones Desde La Práctica. Eutopía - Revista de Desarrollo Económico Territorial, (1), 2010a.

GALLICCHIO, E. ¿El desarrollo local está de moda? Conceptos Críticos, 2(1), 1-12, 2010b.

GIRALDO, M. E. La Privatización de las Telecomunicaciones en Colombia. Gestión y Política Pública, 25(1), p. 81-117, 2016

MARIÑEZ, F. (2017). Innovación Pública en América Latina: Conceptos, Experiencias exitosas, Desafíos y Obstáculos. Revista de Gestión Pública, VI (1), 5-18,2017.

MANRIQUE, A. Gestión y diseño: Convergencia disciplinar. Pensamiento y gestión, (40), p. 129-158, 2016.

MEDINA. C. La gestión social integral en el contexto de la gestión pública participativa. En C. Medina, A. Roth y Hernández, (Eds.), La Gestión Pública Participativa en el contexto de la Gestión Social Integral. Nociones y conceptos, Bogotá, Colombia: Editorial Kimpres Ltda, p.155, 2008.

MUÑOZ, P. De los modelos de gestión pública al territorio. En: Sánchez y Liendo (E.,) Manual de Ciencia Política y Relaciones Internacionales. Bogotá: Universidad Sergio Arboleda, 2020

MUÑOZ, P., y FONTAINE, G. (2019). La participación ciudadana en la política de lucha contra la pobreza rural en Colombia. Cuadernos del Cendes 36(100), p. 81-106

NASER A. and RAMÍREZ-ALUJAS, Á. Plan de gobierno abierto. Una hoja de ruta para los gobiernos de la región. Series Manuales. Santiago de Chile: Naciones Unidas, 2014

MUÑOZ, H. La burocracia universitaria. Revista de la Educación Superior 48 (189). p. 73-96, 2019.

MOORE, H. M. Gestión estratégica y creación de valor en el sector público. En: S. Paidós Ibérica, S.A. Barcelona y Ed. Paidós (Ed.), Gestión estratégica y creación de valor en el sector público. Buenos Aires, 1998.

NASER, A., FIDELEFF V., and TOGNOLI, J. Gestión de planes de acción locales de gobierno abierto: herramientas para la cocreación, el seguimiento y la evaluación. Documentos de Proyectos (LC/TS.2020/78), Santiago, Comisión Económica para América Latina y el Caribe (CEPAL), 2020.

OSZLAK, O. Gobierno abierto: hacia un nuevo paradigma de gestión pública. Red de Gobierno Electrónico de América Latina y El Caribe - Red GEALC, 5, 2013.

PEREIRA, M., and JARÁIZ, E., (2015). El Nuevo Servicio Público (NSP), un paradigma para la construcción de nuevos modelos metodológicos para el análisis de la administración pública. RIPS 14 (2), p.73-94, 2015

RAMÍREZ-ALUJAS, Á. (2020). El estado del Estado abierto en América Latina: avances, alcances y perspectivas. Estado Abierto. Revista Sobre El Estado, La Administración Y Las Políticas Públicas, 4(1). p. 13-38, 2020. 
RAMÍREZ-ALUJAS, Á. (2011). Gobierno abierto y modernización de la gestión Pública. Tendencias actuales y el (inevitable) camino que viene. Reflexiones semifinales. Enfoques: Ciencia Política y Administración Pública, (9), p. 99-125, 2011.

RESTREPO, D. Aportes para el análisis del gobierno abierto en Nariño. (Tesis de pregrado). Pontificia Universidad Javeriana, Bogotá, Colombia, 2017

SERNA, J.M. (2010). Gobernanza, privatización y “nueva” regulación (Capítulo tercero). México: $\begin{array}{llllllll}\text { UNAM } & \text { Recuperado el } & 2 & \text { de } & \text { julio }\end{array}$ https://archivos.juridicas.unam.mx/www/bjv/libros/6/2818/6.pdf

RAMIÓ, CH. La burocracia: origen y destino Recuperado el 20 de marzo de 2020 de https://www.administracionpublica.com/la-burocracia-origen-y-destino/

ROSAS, F., CALDERÓN, J., y CAMPOS, H. Elementos conceptuales para el análisis de la gobernanza territorial Conceptual elements for analysis of territorial governance. Quivera, p. 113-136, 2012.

RUCALVA, E. Datos abiertos. Eunomía. Revista en Cultura de la Legalidad, (18), p. 327-334, 2020.

ROTH, A. Políticas públicas. Formulación, implementación y evaluación. 10ª edición actualizada. Bogotá, Colombia: Ediciones Aurora, 2015.

SABATIER, P., and MAZMANIAN, D. The Conditions of Effective Implementation: A Guide to Accomplishing Policy Objectives. Policy Analysis (5), 481-504, 1979

SANTILLÁN, J. Valor público, gobernanza y Tercera Vía. Convergencia Revista de Ciencias (78), p. 177-193, 2018

VALDEZ ZEPEDA, A. Paradigmas emergentes en la gestión pública en América Latina. Revista Venezolana De Gerencia, 24(86), p.325-339, 2019. 